\section{In Vitro Shoot Regeneration of Georgia Plume, Elliottia racemosa, from Multiple Genotypes Collected from Wild Populations}

\author{
Carrie A. Radcliffe, James M. Affolter, and Hazel Y. Wetzstein ${ }^{1}$ \\ Department of Horticulture, 1111 Miller Plant Science Building, The \\ University of Georgia, Athens, GA 30602
}

Additional index words. conservation, tissue culture, micropropagation

\begin{abstract}
Georgia plume (Elliottia racemosa, Ericaceae) is a threatened, woody plant endemic to Georgia's Coastal Plain region in the southeastern United States. Populations of the plant have a fragmented distribution within a restricted range and are characterized by low genetic diversity and a lack of sexual recruitment. Georgia plume cannot be effectively propagated using conventional methods. We have developed an in vitro shoot regeneration system that is effective with explants obtained from mature plants in the wild. The objective of this study was to determine the efficacy of using this in vitro protocol to regenerate proliferating shoot cultures from 34 georgia plume genotypes obtained from divergent populations. Young expanding leaves were cultured on Gamborg's media supplemented with $10 \mu M$ thidiazuron and $5 \mu M$ indole-3-acetic acid. After 8 weeks, tissues were transferred to a shoot elongation medium with $25 \mu \mathrm{M}$ 2-isopentenyl adenine. Of the 34 genotypes tested, $91 \%$ formed shoot primordia and $85 \%$ regenerated shoots within 6 months of inoculation. This study verifies that tissue culture can be used to produce adventitious shoots from a wide range of georgia plume genotypes. Within a coordinated conservation program, tissue culture is a feasible system to use for safeguarding and reintroduction of genetically diverse plant material, which may be critical to the survival of this rare species.
\end{abstract}

Georgia plume (Elliottia racemosa, Ericaceae) is a tree endemic to the Coastal Plain region of Georgia in the southeastern United States. It was first discovered by the explorer, William Bartram, in 1773 and documented by botanist Stephen Elliott in 1807. It was so rare that after this time, the species was thought to be extinct until its rediscovery in 1901 . Georgia plume grows on sand ridges, dry oak ridges, evergreen hammocks, and sandstone outcrops (Patrick et al., 1995). Its distribution has been fragmented by land development and the decline of a suitable habitat. Georgia plume is currently found in less than 36 populations in 19 counties. Georgia plume is listed as threatened in the state of Georgia but has no Federal listing (Chafin, 2007).

Georgia plume is a striking deciduous tree growing up to $\approx 9 \mathrm{~m}$ tall. Plume-like racemes of white flowers appear in early summer. When capsules develop, they ripen in the fall; however, the main mode of reproduction is vegetative through root suckers. In recent times no seedlings have been documented in the wild, indicating an absence of sexual recruitment.

Received for publication 1 Nov. 2010. Accepted for publication 4 Dec. 2010.

We thank Ron Determann and the Atlanta Botanical Garden for the continued maintenance of the genotypes established in this study from populations in the wild.

${ }^{1}$ To whom reprint requests should be addressed; e-mail HYWetz@uga.edu.
There is a high occurrence of inviable seed both in cultivation and in the wild (Bozeman and Roger, 1983; Fordham, 1969). Low pollen viability and gametophytic self-incompatibility have been observed in georgia plume and may be contributing to sexual failure in this species (Radcliffe, 2009). Because of its rarity and desirable ornamental characteristics, attempts to propagate georgia plume have been made, yet conventional techniques have not been effective. Propagation by shoot cuttings has been unsuccessful, and root cuttings can produce only a limited number of shoots (Fordham, 1991). Scanty population numbers and lack of sexual reproduction may lead to the demise of this plant, which has low genetic diversity at both the population and species level (Godt and Hamrick, 1999).

Georgia plume is a prime candidate for ex situ cultivation, which can be used to generate plants for reintroduction and safeguarding purposes. Ex situ propagation efforts often play an integral role in plant conservation (Guerrant et al., 2004; Maunder and Culham, 1999). Tissue culture has been used to propagate rare species (Fay, 1992; Fay et al., 1999; Sarasan et al., 2006) and is a powerful conservation tool that can facilitate the propagation of a species using limited amounts of stock material (Merkle, 1999). It is especially useful when reproductive failure occurs in the wild (Guerrant et al., 2004).

A number of threatened and endangered woody species have been regenerated using tissue culture. Betula uber, confined to a single population, was propagated by axillary shoot proliferation (Vijayakumar et al., 1990). Shoot tip cultures of the endemic shrub Decalepis arayalpathra were multiplied, elongated, and rooted in vitro (Sudha et al., 2005). Rhododendron ponticum subsp. baeticum, which like georgia plume belongs to the Ericaceae, and similarly has restricted populations, contains only adult trees with no signs of seedling recruitment (Almeida et al., 2005). Micropropagation allowed the reintroduction of plants into their native habitats.

An effective micropropagation protocol for georgia plume has been established by Woo and Wetzstein (2008a, 2008b). In this system, adventitious shoot buds were induced from leaf explants cultured on a medium containing $10 \mu \mathrm{M}$ thidiazuron (TDZ) and $5 \mu \mathrm{M}$ indole-3-acetic acid (IAA). Shoots were elongated on a secondary medium supplemented with $25 \mu \mathrm{M}$ 2-isopentenyl adenine (2iP) and were successfully rooted both in vitro and ex vitro. However, responses to in vitro culture can be very genotype-dependent (Gandonou et al., 2005; Riseman and Chennareddy, 2004), and optimization may be needed to compensate for this variation (Debnath, 2003, 2007; Gupta et al., 2006; Khanna and Raina, 1998). As part of our overall conservation efforts for georgia plume, an aim of current studies is to define effective protocols for the reintroduction and augmentation of natural populations.

The objective of this study was to determine the efficacy of using an in vitro protocol to regenerate proliferating shoot cultures from 34 georgia plume genotypes obtained from divergent wild populations. Clonal propagation of genotypes from existing wild populations can be used as a conservation tool to provide germplasm for ex situ safeguarding and to generate plant material for re-establishment in situ, thus preserving the genetic diversity of this species.

\section{Materials and Methods}

Field collections were made from populations throughout the natural range of georgia plume. Cultures were initiated from leaves collected from plants in the field for 34 different genotypes representing 12 wild populations (Table 1). Letters were arbitrarily assigned to designate populations and numbers assigned to different genotypes. These populations have been characterized using GPS/GIS and DNA analyses (Porter, 2010) that will allow us to revisit populations. Samples were collected from trees that were at least $15 \mathrm{~m}$ apart to ensure material was collected from different genotypes and not suckers. Collections were made in the spring, 21 Apr. to 6 May 2009, when leaves were young (less than $2 \mathrm{~cm}$ long), light green, and at the expanding stage. Leaf tissue at this stage is the most regenerable (Woo and Wetzstein, 2008a). Generally, three genotypes per population were initiated, and 30 to 40 explants were cultured per genotype.

Leaves were disinfected as described by Woo and Wetzstein (2008a). Briefly, leaves were washed for 20 min in tap water containing a few drops of antibacterial hand soap, rinsed in water, then placed sequentially in $70 \%$ 
ethanol for $60 \mathrm{~s}, 10 \%$ Roccal (v/v) (National Laboratories, Montvale, NJ) for $10 \mathrm{~min}$, and $1.2 \%$ sodium hypochlorite for $10 \mathrm{~min}$ followed by three washes in sterile distilled water. Leaves were cut into pieces $\approx 5 \times 5 \mathrm{~mm}$ and cultured abaxial side down onto induction medium consisting of Gamborg's $B_{5}$ salts (Gamborg et al., 1968) amended with $10 \mu \mathrm{M}$ TDZ, $5 \mu \mathrm{M}$ IAA, $10 \mathrm{mg} \cdot \mathrm{L}^{-1}$ thiamine $\mathrm{HCl}$, $1 \mathrm{mg} \cdot \mathrm{L}^{-1}$ pyridoxine $\mathrm{HCl}, 1 \mathrm{mg} \cdot \mathrm{L}^{-1}$ nicotinic acid, $40 \mathrm{~g} \cdot \mathrm{L}^{-1}$ maltose, and $4 \mathrm{~g} \cdot \mathrm{L}^{-1}$ Gel-Gro (ICN Biochemicals, Aurora, OH). The medium was adjusted to $\mathrm{pH} 6.0$, dispensed in $20-\mathrm{mL}$ aliquots into test tubes, and autoclaved at $121{ }^{\circ} \mathrm{C}$ for $20 \mathrm{~min}$. Genotypic responses to tissue culture were assessed weekly for 4 weeks. Cultures were considered responsive if swelling and callusing of the explants were evident. Cultures were transferred onto fresh induction media at Week 4. Cultures were rated for formation of shoot primordia and buds while on induction medium at 4 and 8 weeks.

After 8 weeks on induction media, cultures were transferred to shoot elongation medium consisting of Woody Plant Medium (WPM) (Lloyd and McCown, 1980) amended with 25 $\mu \mathrm{M} 2 \mathrm{iP}, 2 \mathrm{mg} \cdot \mathrm{L}^{-1}$ glycine, $0.5 \mathrm{mg} \cdot \mathrm{L}^{-1}$ nicotinic acid, $0.5 \mathrm{mg} \cdot \mathrm{L}^{-1}$ pyridoxine $\mathrm{HCl}, 1 \mathrm{mg} \cdot \mathrm{L}^{-1}$ thiamine $\mathrm{HCl}, 100 \mathrm{mg} \cdot \mathrm{L}^{-1}$ myo-inositol, 20 $\mathrm{g} \cdot \mathrm{L}^{-1}$ sucrose, and $4 \mathrm{~g} \cdot \mathrm{L}^{-1} \mathrm{Gel}-\mathrm{Gro}$. The medium was adjusted to $\mathrm{pH} 5.2$, distributed in $30-\mathrm{mL}$ aliquots into $66 \mathrm{~mm} \times 59$-mm glass jars, and autoclaved at $121^{\circ} \mathrm{C}$ for $20 \mathrm{~min}$. The cultures were maintained under a $16-\mathrm{h}$ photoperiod under white fluorescent lights (70 $\left.\mu \mathrm{mol} \cdot \mathrm{m}^{-2} \cdot \mathrm{s}^{-1}\right)$ at $25^{\circ} \mathrm{C}$ and transferred onto fresh media every 4 weeks. Shoot elongation was rated at each transfer to shoot elongation media for 16 weeks.

Statistical analyses were performed using analysis of variance, least squares means, and Duncan's mean separation $(P \leq 0.05)$ procedures within the general linear model procedure of SAS (Version 9.1 for Windows; SAS Institute Inc., Cary, NC).

\section{Results and Discussion}

The responsiveness of E. racemosa leaf explants placed on induction media was characterized by swelling and callusing of tissues and was followed by shoot organogenesis. This growth was the result of cell division and enlargement of spongy and mesophyll

Table 1. Details of natural populations and locations in the state of Georgia from which leaf tissues were collected for in vitro culture initiation.

\begin{tabular}{lcl}
\hline Location name & Population & County \\
\hline Little River & A & Turner \\
Unnamed & C & Bryan \\
Big Hammock & D & Tattnal \\
Little Hammock & F & Tattnal \\
Charles Harrold Preserve & J & Candler \\
Mertz Pond (Fort Stewart) & $\mathrm{K}$ & Tattnal \\
Unnamed (Fort Stewart) & $\mathrm{L}$ & Bryan \\
Unnamed (Fort Stewart) & $\mathrm{M}$ & Evans \\
Unnamed (Fort Stewart) & $\mathrm{N}$ & Evans \\
Unnamed (Fort Stewart) & $\mathrm{O}$ & Evans \\
Unnamed (Fort Stewart) & $\mathrm{P}$ & Evans \\
Unnamed (Fort Stewart) & $\mathrm{Q}$ & Evans \\
\hline
\end{tabular}

cells. Promeristematic structures are reported to form from the outer mesophyll layers close to the surface of explants with organized meristematic regions exposed through discontinuities in the epidermal layer as proliferation progresses (Woo and Wetzstein, 2008b). Further expansion leads to the development of adventitious shoots.

The number of responding explants and the frequency of explant response varied with genotype. Response was generally rapid with swelling and callusing observed in $79 \%$ of the genotypes 1 week after culture initiation and in $97 \%$ of genotypes by 2 weeks after initiation (data not given). The number and extent of responding genotypes increased with time. All genotypes showed some level of response with the percent of explants responding for a genotype ranging from $20 \%$ to $100 \%$ by Week 4 (Table 2). At 4 weeks after initiation, 79\% of the genotypes had $80 \%$ or more of explants exhibiting swelling and callusing; only $3 \%$ of the genotypes had less than $25 \%$ response.

Many of the genotypes (over 65\%) produced shoot or bud primordia by 4 weeks after initiation (Table 2). The timing of adventitious shoot formation varied with genotype. Three genotypes (Q33, D8, L18) exhibited significantly greater regeneration and had $95 \%$ to $100 \%$ of explants forming shoot primordia by 4 weeks after initiation. Some genotypes required a longer period for shoot development. Although all genotypes elicited callusing by 4 weeks, $35 \%$ had no shoot primordia at this time. However, by 8 weeks after culture initiation, $94 \%$ of the genotypes had cultures with differentiated shoot primordia. The response of cultures was generally strong. Over $70 \%$ of the genotypes had $50 \%$ or more of explants forming shoots; $50 \%$ of the genotypes had over $80 \%$ of explants producing adventitious shoots.

Shoots obtained on induction media with TDZ and IAA were prolific (Fig. 1A) but required elongation before shoots were effective for rooting. To promote shoot elongation and leaf expansion, cultures were transferred onto WPM containing $25 \mu \mathrm{M} 2 \mathrm{iP}$. After 4 weeks on elongation media, $41 \%$ of the genotypes had elongated shoots (data not shown).

Table 2. The response of georgia plume (Elliottia racemosa) leaf explant cultures initiated from 34 genotypes collected from populations in the wild. ${ }^{z}$

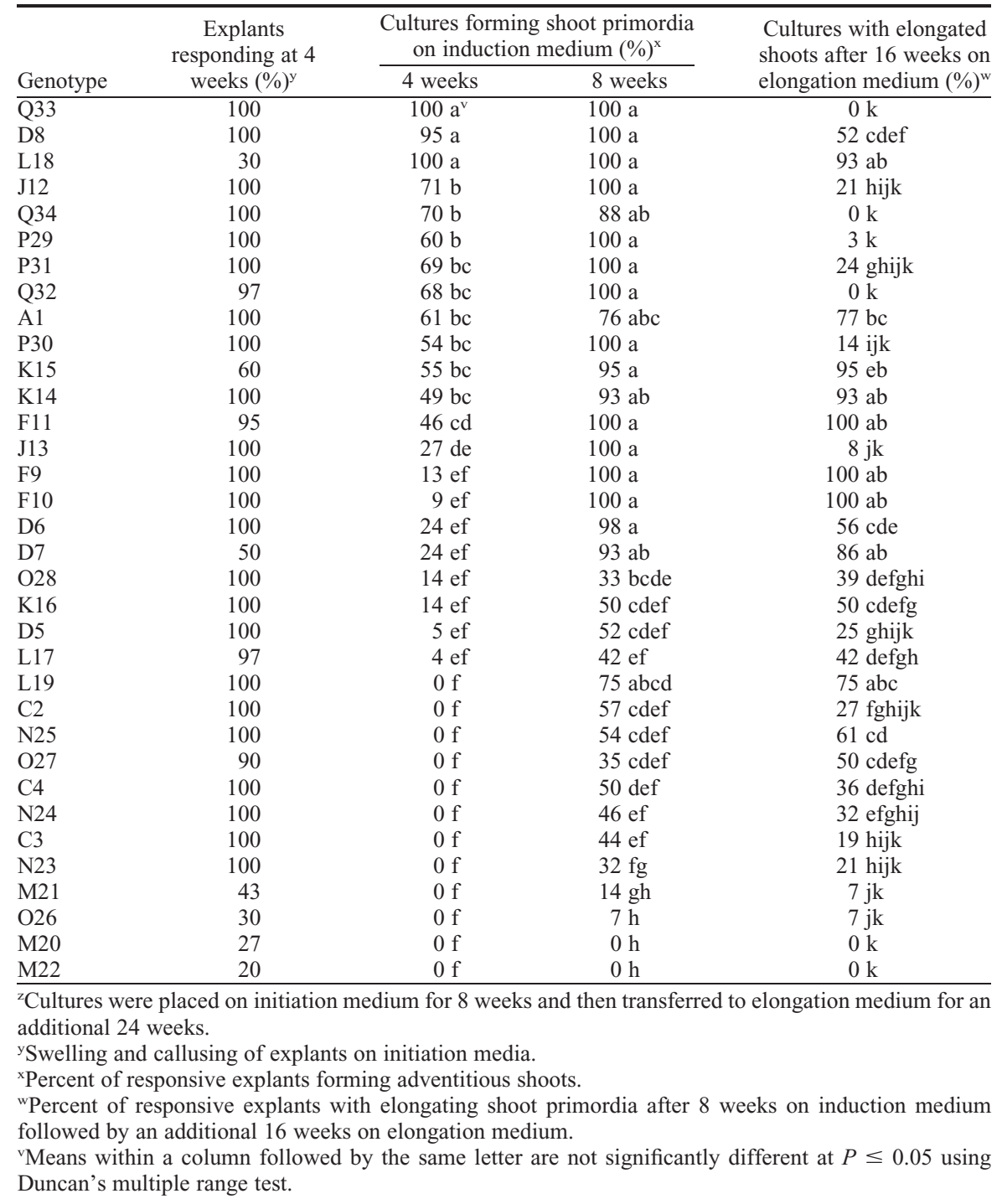


Greater shoot elongation was observed with subsequent subcultures on elongation medium. Genotypic differences were observed in shoot elongation patterns and leaf size (Fig. 1B). Foliage color also varied with genotype and ranged from light to dark green with some genotypes producing reddish leaves. The use of an elongation medium with $2 \mathrm{iP}$ was generally effective, but the efficacy varied with genotype. After 16 weeks on elongation media (24 weeks after initiation), cultures of $85 \%$ of the genotypes produced elongated shoots with a frequency from $0 \%$ to $100 \%$ (Table 2). Similar genotypic variations in response to $2 \mathrm{iP}$ were observed in rhododendron (Anderson, 1984; Iapichino et al., 1992). Shoot morphology/ height of a genotype after culture on elongation medium was not related to explant responsiveness or capacity to produce shoot primordia.

TDZ reportedly inhibits the elongation of shoots, and transferring cultures to a medium containing lower levels or a less active cytokinin can be effective in overcoming this inhibition (Huetteman and Preece, 1993). The use of a two-stage system in which shoots were initiated on an induction medium supplemented with TDZ and subsequently elongated on a secondary medium was efficient for the regeneration of shoots from many woody species (Debnath, 2003, 2005b; Huetteman and Preece, 1993; Vijaya Chitra and Padmaja, 2005; Woo and Wetzstein, 2008a). Similar protocols have been developed for economically important members of the Ericaceae, including blueberry, cranberry, lingonberry, and rhododendron in which TDZ was used alone or in combination with $2 \mathrm{iP}$ or IAA to promote shoot regeneration (Cao and Hammerschlag, 2000; Debnath, 2005a, 2009; Marcotrigiano and McGlew, 1991).

Some genotypes (Q33, Q34, Q32, P29, J13) produced high numbers of shoot primordia on induction medium but produced few or no elongated shoots on transfer to a medium with 2iP (Table 2). Further optimization of elongation medium composition is needed to provide greater numbers of shoots suitable for rooting in these unresponsive georgia plume genotypes. In genotypes producing short shoots, the use of benzyladenine may be beneficial. This has been used to promote elongation of shoots in azalea (Briggs et al., 1988) and mulberry (Vijaya Chitra and Padmaja, 2005) after shoot initiation on a medium containing TDZ. Zeatin has been successful in improving shoot regeneration in cultivars of blueberry (Cao and Hammerschlag, 2000) and in the endangered Rhododendron ponticum subsp. baeticum (Cantos et al., 2007). Incorporation of zeatin into secondary media promoted rapid elongation of lingonberry shoots induced from leaf explants using TDZ (Debnath, 2005b).

To evaluate the 12 different georgia plume populations, means for individual genotypes were nested within their respective populations and compared. The population data are shown in Table 3. All populations had explants forming callus by 4 weeks on initiation medium with over $70 \%$ response observed in 11 of the 12 populations. Population M exhibited a lower response (30\%). Significant
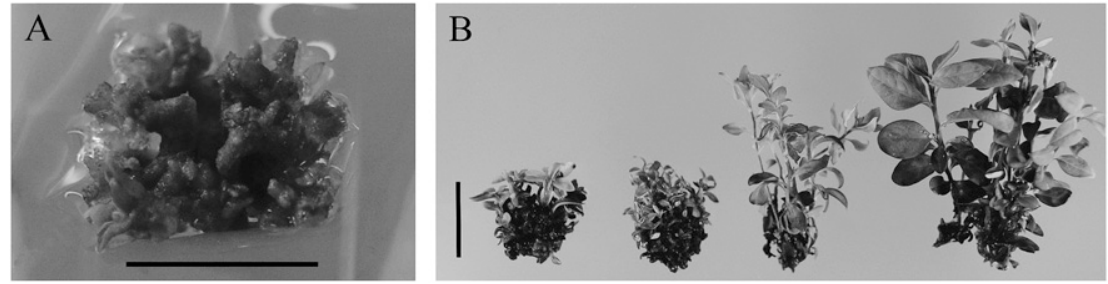

Fig. 1. Georgia plume shoots obtained from in vitro cultures. (A) Adventitious shoot primordia initiated on an induction medium with thidiazuron. Scale bar $=5 \mathrm{~mm}$. (B) Variation in shoot elongation observed in cultures originating from different wild populations after transfer to an elongation medium. Scale bar $=$ $2 \mathrm{~cm}$.

Table 3. The response of 12 populations of georgia plume (Elliottia racemosa). ${ }^{\mathrm{z}}$

\begin{tabular}{|c|c|c|c|c|}
\hline \multirow[b]{2}{*}{ Population } & \multirow{2}{*}{$\begin{array}{l}\text { Explants responding } \\
\text { at } 4 \text { weeks }(\%)^{\mathrm{y}}\end{array}$} & \multicolumn{2}{|c|}{ Cultures with shoot primordia $(\%)^{\mathrm{x}}$} & \multirow{2}{*}{$\begin{array}{l}\text { Cultures with elongated } \\
\text { shoots after } 24 \text { weeks on } \\
\text { elongation medium }(\%)^{\mathrm{w}}\end{array}$} \\
\hline & & 4 weeks & 8 weeks & \\
\hline$\overline{\mathrm{Q}}$ & 99 & $79 \mathrm{a}^{\mathrm{v}}$ & $96 \mathrm{ab}$ & $0 \mathrm{~g}$ \\
\hline $\mathrm{P}$ & 100 & $61 \mathrm{ab}$ & $100 \mathrm{abc}$ & $14 \mathrm{fg}$ \\
\hline A & 100 & $61 \mathrm{ab}$ & $76 \mathrm{c}$ & $77 \mathrm{~b}$ \\
\hline $\mathrm{J}$ & 100 & $49 \mathrm{c}$ & $100 \mathrm{abc}$ & $15 \mathrm{efg}$ \\
\hline $\mathrm{D}$ & 88 & $37 \mathrm{c}$ & $86 \mathrm{abc}$ & $55 \mathrm{c}$ \\
\hline $\mathrm{K}$ & 87 & $39 \mathrm{~cd}$ & $79 \mathrm{bc}$ & $79 \mathrm{~b}$ \\
\hline $\mathrm{L}$ & 76 & $34 \mathrm{dc}$ & $72 \mathrm{c}$ & $70 \mathrm{bc}$ \\
\hline $\mathrm{F}$ & 98 & $23 \mathrm{e}$ & $100 \mathrm{abc}$ & $100 \mathrm{a}$ \\
\hline $\mathrm{O}$ & 73 & $5 \mathrm{ef}$ & $41 \mathrm{~d}$ & 32 def \\
\hline $\mathrm{C}$ & 100 & $0 \mathrm{f}$ & $50 \mathrm{~d}$ & $27 \mathrm{def}$ \\
\hline $\mathrm{N}$ & 100 & $0 \mathrm{f}$ & $44 \mathrm{~d}$ & $38 \mathrm{def}$ \\
\hline M & 30 & $0 \mathrm{f}$ & $5 \mathrm{e}$ & $2 \mathrm{~g}$ \\
\hline
\end{tabular}

${ }^{\mathrm{z}}$ Cultures were initiated from leaf explants placed on initiation medium for 8 weeks and then transferred to elongation medium for 4 months. Data represent means of genotypes within each population.

${ }^{y}$ Swelling and callusing of explants on initiation media.

xPercent of responsive explants with adventitious shoots.

wPercent of responsive explants with elongating shoots after 8 weeks on induction medium followed by an additional 16 weeks on shoot elongation medium.

${ }^{v}$ Means within a column followed by the same letter are not significantly different at $P \leq 0.05$ using Duncan's multiple range test.

differences in the formation of shoot primordia were observed among populations. Three populations $(\mathrm{Q}, \mathrm{P}, \mathrm{A})$ had significantly higher percentages of cultures forming shoots at 4 weeks with $61 \%$ or more of the cultures forming shoot primordia. Seven populations had $34 \%$ or more of cultures forming shoot primordia by 4 weeks; five populations ( $\mathrm{F}, \mathrm{O}$, $\mathrm{C}, \mathrm{N}, \mathrm{M}$ ) produced significantly fewer shoots. The presence of shoot primordia increased with time. After 8 weeks on initiation medium, eight populations had $72 \%$ or more of cultures forming shoot primordia. Three populations had significantly lower percentages $(41 \%$ to $50 \%$ ) of cultures developing shoot primordia. Population $\mathrm{M}$ had the lowest shoot primordia formation $(5 \%)$, even after 8 weeks. According to the analysis of variance results, most of the variation in the ability of leaf explants of georgia plume to form adventitious shoots in vitro was attributable to population (59\%), whereas the amount attributable to individual genotypes was much less (14\%).

Population effects were likewise observed in the extent of shoot elongation observed after transfer to elongation medium with $2 \mathrm{iP}$. Population $\mathrm{F}$ had significantly more cultures with elongated shoots $(100 \%)$ after 16 weeks on elongation medium (24 weeks from initiation). Also, significantly more responses were noticed in Populations K (79\%), A (77\%), L $(70 \%)$, and $\mathrm{D}(55 \%)$. The remaining seven populations had less than $38 \%$ of cultures with elongated shoots at this time. However, further elongation was observed in some of these genotypes after further subculture on elongation media (data not shown). Shoots maintained on a medium with $2 \mathrm{iP}$ continued to proliferate and remain productive.

The differential responses of genotypes from the different populations to in vitro propagation may have a genetic basis. Population surveys by Porter (2010) found that many existing georgia plume populations are isolated and composed of fewer than 50 individuals. Inbreeding among closely related individuals may be occurring. Likewise, environmental conditions and local adaptations within plant populations could be contributing to the different responses observed in in vitro culture. Habitat fragmentation, decreased population size, and increased isolation may influence the degree of local adaptation (Becker et al., 2006). Genotype-environment interactions have been documented to affect plant chemistry and defense (Mosleh Arany et al., 2009). Although genotypic limitation can be a significant constraint in micropropagation (Gupta et al., 2006), the current protocol appears to be effective with many genotypes and populations of georgia plume.

Georgia plume cultures have been maintained on elongation media for $\approx 1$ year after the completion of this study. Genotypes are 
being safeguarded in vitro at the Atlanta Botanical Garden (Atlanta, GA). The transfer of cultures to a half-strength basal medium has encouraged further shoot elongation with spontaneous rooting occurring in some genotypes. Plants from most genotypes have been regenerated and easily acclimatized to greenhouse conditions when placed under a fog system for 3 to 4 weeks (C. Radcliffe, personal communication). Plants are currently continuing to thrive and will be planted in the Atlanta Botanical Garden's safeguarding nursery.

The tissue culture protocol developed for georgia plume was highly effective in producing adventitious shoots in a broad range of genotypes originating from divergent populations. The use of leaf tissue provides a source of highly regenerable tissues from mature individuals collected from natural populations in the wild. It is feasible to use this system for ex situ propagation of $E$. racemosa to generate genetically diverse plant material for safeguarding, reintroduction, and augmentation of existing populations. Such efforts may be critical to the survival of this rare species as it faces the threat of extinction.

\section{Literature Cited}

Almeida, R., S. Goncalves, and A. Romano. 2005. In vitro micropropagation of endangered Rhododendron ponticum L. subsp. baeticum (Boissier \& Reuter) Handel-Mazzetti. Biodivers. Conserv. 14:1059-1069.

Anderson, W.C. 1984. A revised tissue culture medium for shoot multiplication of Rhododendron. J. Amer. Soc. Hort. Sci. 109:343-347.

Becker, U., G. Colling, P. Dostal, A. Jakobsson, and D. Matthies. 2006. Local adaptation in the monocarpic perennial Carlina vulgaris at different spatial scales across Europe. Oecologia 150:506-518.

Bozeman, J.R. and G.A. Roger. 1983. Final status report in Elliottia racemosa Muhl. ex Ell., the Georgia plume. US Dept. Interior Fish Wildlife Serv., Reg. IV.

Briggs, B.A., S.M. McCulloch, and L.A. Edick. 1988. Micropropagation of azaleas using thidiazuron. Acta Hort. 227:330-333.

Cantos, M., J. Linan, J.L. Garcia, M. Garcia-Linan, M.A. Dominguez, and A. Troncoso. 2007. The use of in vitro culture to improve the propagation of Rhododendron ponticum subsp. baeticum (Boiss. \& Reuter). Central Europ. J. Biol. 2:297306.

Cao, X. and F.A. Hammerschlag. 2000. Improved shoot organogenesis from leaf explants of highbush blueberry. HortScience 35:945-947.

Chafin, L.G. 2007. Field guide to the rare plants of Georgia. State Botanical Garden of Georgia, Athens, GA.

Debnath, S.C. 2003. Improved shoot organogenesis from hypocotyl segments of lingonberry ( $\mathrm{Vac}$ - cinium vitis-idaea L.). In Vitro Cell. Dev. Biol. Plant 39:490-495.

Debnath, S.C. 2005a. Micropropagation of lingonberry: Influence of genotype, explant orientation, and overcoming TDZ-induced inhibition of shoot elongation using zeatin. HortScience 40: 185-188.

Debnath, S.C. 2005b. A two-step procedure for adventitious shoot regeneration from in vitroderived lingonberry leaves: Shoot induction with TDZ and shoot elongation using zeatin. HortScience 40:189-192.

Debnath, S.C. 2007. Strategies to propagate Vaccinium nuclear stocks for the Canadian berry industry. Can. J. Plant Sci. 87:911-922.

Debnath, S.C. 2009. A two-step procedure for adventitious shoot regeneration on excised leaves of lowbush blueberry. In Vitro Cell. Dev. Biol. Plant 45:122-128.

Fay, M.F. 1992. Conservation of rare and endangered plants using in vitro methods. In Vitro Cell. Dev. Biol. Plant 28:1-4.

Fay, M.F., E. Bunn, and M.M. Ramsay. 1999. In vitro propagation, p. 97-107. In: Bowes, B.G. (ed.). A color atlas of plant propagation and conservation. Manson Pub., London, UK.

Fordham, A.J. 1969. Elliottia racemosa and its propagation. Arnoldia 29:17-20.

Fordham, A.J. 1991. Elliottia racemosa and its propagation. Arnoldia 51:59-62.

Gamborg, O.L., R.A. Miller, and K. Ojima. 1968. Nutrient requirements of suspension cultures of soybean root cells. Exp. Cell Res. 50:151158.

Gandonou, C., T. Errabii, J. Abrini, M. Idaomar, F. Chibi, and N.S. Senhaji. 2005. Effect of genotype on callus induction and plant regeneration from leaf explants of sugarcane (Saccharum sp.). Afr. J. Biotechnol. 4:1250-1255.

Godt, M.J.W. and J.L. Hamrick. 1999. Population genetic analysis of Elliottia racemosa (Ericaceae), a rare Georgia shrub. Mol. Ecol. 8:7582.

Guerrant, E.O., K. Havens, and M. Maunder. 2004. Ex situ plant conservation: Supporting species survival in the wild. Island Press, Washington, DC.

Gupta, S., V.K. Khanna, R. Singh, and G.K. Garg. 2006. Strategies for overcoming genotypic limitations of in vitro regeneration and determination of genetic components of variability of plant regeneration traits in sorghum. Plant Cell Tissue Organ Cult. 86:379-388.

Huetteman, C.A. and J.E. Preece. 1993. Thidiazuron: A potent cytokinin for woody plant tissue culture. Plant Cell Tissue Organ Cult. 33:105-119.

Iapichino, G., S. McCulloch, and T.H.H. Chen. 1992. Adventitious shoot formation from leaf explants of Rhododendron. Plant Cell Tissue Organ Cult. 30:237-241.

Khanna, H.K. and S.K. Raina. 1998. Genotype $\times$ culture media interaction effects on regeneration response of three indica rice cultivars. Plant Cell Tissue Organ Cult. 52:145-153.

Lloyd, G. and B. McCown. 1980. Commercially feasible micropropagation of mountain laurel,
Kalmia latifolia, by use of shoot tip culture. Proc. Intl. Plant Prop. Soc. 20:421-427.

Marcotrigiano, M. and S.P. McGlew. 1991. A 2stage micropropagation system for cranberries. J. Amer. Soc. Hort. Sci. 116:911-916.

Maunder, M. and A. Culham. 1999. Plant diversityDistribution, measurement and conservation, $\mathrm{p}$. 25-36. In: Bowes, B.G. (ed.). A colour atlas of plant propagation and conservation. Manson Pub., London, UK.

Merkle, S.A. 1999. Application of in vitro culture (IVC) for conservation of forest trees, p. 119 130. In: Bowes, B.G. (ed.). A colour atlas of plant propagation and conservation. Manson Pub., London, UK.

Mosleh Arany, A., T.J. de Jong, H.K. Kim, N.M. van Dam, Y.H. Choi, H.G.J. van Mil, R. Verpoorte, and E. van der Meijden. 2009. Genotype-environment interactions affect flower and fruit herbivory and plant chemistry of Arabidopsis thaliana in a transplant experiment. Ecol. Res. 24:1161-1171.

Patrick, T., J. Allsison, and G. Krakow. 1995. Protected plants of Georgia. Georgia Dept. Natural Resources, Social Circle, GA.

Porter, J. 2010. Conserving our botanical heritage: Using GPS/GIS and molecular analysis as conservation management tools for georgia plume (Elliottia racemosa). MS thesis, Univ. of Georgia, Athens, GA.

Radcliffe, C.A. 2009. Studies in reproductive biology and in vitro propagation as approaches for the conservation of Elliottia racemosa. MS thesis, Univ. of Georgia, Athens, GA.

Riseman, A. and S. Chennareddy. 2004. Genotypic variation in the micropropagation of Sri Lankan Exacum hybrids. J. Amer. Soc. Hort. Sci. 129: 698-703.

Sarasan, V., R. Cripps, M.M. Ramsay, C. Atherton, M. McMichen, G. Prendergast, and J.K. Rowntree. 2006. Conservation in vitro of threatened plants: Progress in the past decade. In Vitro Cell. Dev. Biol. Plant 42:206-214.

Sudha, C.G., P.N. Krishnan, P. Pushpangadan, and S. Seeni. 2005. In vitro propagation of Decalepis arayalpathra, a critically endangered ethnomedicinal plant. In Vitro Cell. Dev. Biol. Plant 41: 648-654.

Vijaya Chitra, D.S. and G. Padmaja. 2005. Shoot regeneration via direct organogenesis from in vitro derived leaves of mulberry using thidiazuron and 6-benzylaminopurine. Sci. Hort. 106: 593-602.

Vijayakumar, N.K., P.P. Feret, and T.L. Sharik. 1990. In vitro propagation of the endangered Virginia roundleaf birch [Betula uber (Ashe) Fern] using dormant buds. For. Sci. 36:842-846.

Woo, S.M. and H.Y. Wetzstein. 2008a. An efficient tissue culture regeneration system for georgia plume, Elliottia racemosa, a threatened Georgia endemic. HortScience 43:447-453.

Woo, S.M. and H.Y. Wetzstein. 2008b. Morphological and histological evaluations of in vitro regeneration in Elliottia racemosa leaf explants induced on media with thidiazuron. J. Amer. Soc. Hort. Sci. 133:167-172. 